\title{
The Nation, the State, and the First Industrial Revolution
}

\author{
Julian Hoppit
}

he nation-state has long offered a powerful framework within which to understand modern economic growth. To some it provides "a natural unit in the study of economic growth," especially when measuring such growth; to many others states have often significantly influenced the performance of their economies. ${ }^{1}$ On this second point Barry Supple observed that "frontiers are more than lines on a map: they frequently define quite distinctive systems of thought and action. The state is, of course, pre-eminently such a system." ${ }^{2}$ In the British case, however, national frontiers have long been highly distinctive, as has recently been made plain by the "new British history" and work by political scientists on devolution since $1997 .^{3}$

By exploring patterns of the use of legislation for economic ends, this article considers the implications of such distinctiveness for the relationship between the nation-state and Britain's precocious economy between 1660 and 1800. The focus is mainly upon legislation at Westminster, but comparisons are also made with enactments at Edinburgh and Dublin to enrich the account. It is argued that if

Julian Hoppit is Astor Professor of British History at University College London.

${ }^{1}$ Simon Kuznets, "The State as a Unit of Economic Growth," Journal of Economic History 11, no. 1 (Winter 1951): 25-41. Work within the regional and global frameworks in recent decades has pointed up the limitations of an exclusive use of the nation as the unit of assessment and analysis. A very useful summary of the regional approach is provided in Pat Hudson, ed., Regions and Industries: A Perspective on the Industrial Revolution in Britain (Cambridge, 1989). For a recent global approach, see R. C. Allen, The British Industrial Revolution in Global Perspective (Cambridge, 2009).

${ }^{2}$ Barry Supple, "The State and the Industrial Revolution, 1700-1914," in The Fontana Economic History of Europe, ed. C. M. Cipolla (London, 1971), 3:5.

${ }^{3}$ There is a very large literature here, but see particularly: J. G. A. Pocock, The Discovery of Islands: Essays in British History (Cambridge, 2005); Linda Colley, Britons: Forging the Nation, 1707-1837 (New Haven, CT, 1992); Steven G. Ellis and Sarah Barber, eds., Conquest and Union: Fashioning a British State, 1485-1725 (Harlow, 1995); Glenn Burgess, ed., The New British History: Founding a Modern State, 1603-1715 (London, 1999); David Eastwood and Laurence Brockliss, eds., A Union of Multiple Identities: The British Isles, c. 1750-c. 1850 (Manchester, 1997); Iain McLean and Alistair McMillan, State of the Union: Unionism and the Alternatives in the United Kingdom since 1707(Oxford, 2005).

Journal of British Studies 50 (April 2011): 307-331

(C) 2011 by The North American Conference on British Studies.

All rights reserved. 0021-9371/2011/5002-0003\$10.00 
some legislation sought to affect the British economy as a whole, the practical application of such legislation often varied between England, Scotland, and Wales. Similarly, public funds, usually with legislative underpinnings, were spent to develop the economies of Ireland and Scotland more directly than was the case in England and Wales. Moreover, such general measures existed alongside many thousand very particular ones, established at the behest of specific propertied interests, that penetrated deep into the interstices of the domestic economy. Here, however, such English interests utilized legislative authority much more readily than their Scottish or Welsh counterparts. Generally the relationship between nation, state, and the first industrial revolution lacked all the clarity one would expect of a composite multinational polity operating amid an unanticipated epochal change. ${ }^{4}$ That relationship was multifaceted and multilayered, but it also operated differently from one nation to the next within Britain. It may be that such variations in the relationship between political power and economic change is what distinguished the British case, not merely the advent of constitutional monarchy or a heightened attachment to "liberty." This raises doubts about reminted Whig or celebratory accounts of British history promulgated over the past quarter century and incidentally of Britain's supposed exemplary history.

The article begins by considering briefly some of the main broad arguments that have been made about the relationship between the British nation-state and industrialization, including the new Whig accounts. Some national variations in the experience of economic change are then suggested. The heart of the article lies in various counts of patterns of parliamentary legislation relating to economic matters in the period, which leads to a summary of the efforts made at the time to improve "national" economies. Finally, the article concludes by considering the implications of national variations in British practical political economy.

The existing literature on the relationship between the state and the economy in Britain between 1660 and 1800 has typically not been much concerned with the significance of nationhood, of similarities and differences in the experiences of Britain's three nations. ${ }^{5}$ A range of fine studies exists about particular instances when the central state sought to influence the economy. Where they focus upon largely local measures, such as enclosures and turnpike roads, understandably the national dimension has been little considered. But even where scholars have examined legislation that was not locally orientated, they have not often engaged with the national dimension. Fine work by Bob Harris and Patrick O'Brien and

\footnotetext{
${ }^{4}$ By the "first industrial revolution" I mean that Britain's economy was transformed in ways that involved a profound break with earlier economic arrangements and before other national economies. The case for such a view, albeit with a focus on England, is made very clear in E. A. Wrigley, Energy and the English Industrial Revolution (Cambridge, 2010).

${ }^{5}$ For example, the fine survey by Ron Harris largely ignores the national dimension: "Government and the Economy, 1688-1850," in The Cambridge Economic History of Modern Britain, ed. Roderick Floud and Paul Johnson, 3 vols. (Cambridge, 2004), 1:204-37. Similarly, despite its title the interesting overview by Lars Magnusson is little concerned with what constituted nations: Nation, State and the Industrial Revolution: The Visible Hand (London, 2009).
} 
his colleagues are unusual in doing so. ${ }^{6}$ Similarly, it is often forgotten that John Brewer's brilliant study of the growth of the fiscal-military state concentrated on England, not Britain, as its title made clear. ${ }^{7}$ Even mercantilism, often viewed as an expression of economic nationalism, has largely been studied with reference to the English case before 1707 and seamlessly expanded to Britain thereafter. Alternatively, English or British mercantilism is seen as having pursued the same strategic objectives as French or Dutch mercantilism and, consequently, as not nationally distinctive save at the tactical level. ${ }^{8}$ Where national distinctions have been drawn most fruitfully, especially by O'Brien, is in relation to the British state's success in raising revenue and waging war, helping in the process to underpin the expansion of important export markets for British industrial goods. ${ }^{9}$ But even here Britain is not usually approached as a multinational polity, and the approach pays little attention to the use of the state's authority to aid growth generated domestically within the important agricultural and service sectors.

The significance of nationhood and the state to economic performance was, of course, considered long and hard in the seventeenth and eighteenth centuries. One strand of this was that in the eighteenth century foreigners began to expatiate upon English exceptionalism (using England and Britain indiscriminately). For example, Johann Archenholz, the Prussian soldier and historian who lived in England between 1769 and 1779, thought that "Great Britain, which cannot naturally be considered, in the balance of Europe, but as belonging to the second order of kingdoms, has been elevated to the rank of one of the first powers in the world by bravery, wealth, liberty, and the happy consequences of an excellent political system." ${ }^{10}$ Like so many, he believed that England and Great Britain were synonyms, with a single political system, introduced after the Glorious Revolution of 1688-89, experienced by all, and productive of power and prosperity across the whole island. Anglomaniacs praised the emergence of stable, mixed government,

\footnotetext{
${ }^{6}$ Bob Harris, Politics and the Nation: Britain in the Mid-Eighteenth Century (Oxford, 2002); Trevor Griffiths, Philip Hunt, and Patrick O'Brien, "Scottish, Irish, and Imperial Connections: Parliament, the Three Kingdoms, and the Mechanization of Cotton Spinning in Eighteenth-Century Britain," Economic History Review 61, no. 3 (August 2008): 625-50.

${ }^{7}$ John Brewer, The Sinews of Power: War, Money and the English State, 1688-1783 (London, 1989). As did other important general interpretations of state formation: Philip Corrigan and Derek Sayer, The Great Arch: English State Formation as Cultural Revolution (Oxford, 1985); M. J. Braddick, State Formation in Early Modern England, c. 1550-1700 (Cambridge, 2000).

${ }^{8}$ For introductions to the large literature, see Jacob Viner, Studies in the Theory of International Trade (New York, 1937); D. C. Coleman, ed., Revisions in Mercantilism (London, 1969); Lars Magnusson, Mercantilism: The Shaping of an Economic Language (London, 1994); Istvan Hont, Jealousy of Trade: International Competition and the Nation-State in Historical Perspective (Cambridge, MA, 2005).

${ }^{9}$ For good summaries of his valuable approach, P. K. O'Brien, “The Britishness of the First Industrial Revolution and the British Contribution to the Industrialization of 'Follower Countries' on the Mainland, 1756-1914," Diplomacy and Statecraft 8, no. 3 (November 1997): 48-67, and "Inseparable Connections: Trade, Economy, Fiscal State, and the Expansion of Empire, 1688-1815," in The Oxford History of the British Empire, ed. W. R. Louis, 5 vols. (Oxford, 1998-2001), 2:54-77.

${ }^{10}$ J. W. Archenholz, A Picture of England (London, 1789), 2:190; Michael Maurer, "Germany's Image of Eighteenth-Century England," in Britain and Germany Compared: Nationality, Society and Nobility in the Eighteenth Century, ed. Joseph Canning and Hermann Wellenreuther (Göttingen, 2001), 13-36.
} 
the extent of entrepreneurialism, and the flexible and open nature of British thought. ${ }^{11}$

Such views sat easily enough with Herbert Butterfield's description of the Whig interpretation of history: that England was a favored nation, which progressed because of an attachment to liberty. ${ }^{12}$ Such an interpretation was never as dominant as is often supposed and by 1930 had been sufficiently challenged for W. C. Sellar and R. J. Yeatman brilliantly to mock its glib pieties in 1066 and All That. But historical fashions do sometimes go round in circles, and in the past quarter century a number of prominent scholars and public figures have declaimed upon the supposedly exceptional national aspects of economic change in England or Britain. This has taken two main forms.

A few have emphasized the importance of nationhood, national identity, or nationalism in explaining Britain's early industrialization. David Landes has argued that "Britain had the early advantage of being a nation . . . a self-conscious, selfaware unit characterized by common identity and loyalty and by equality of civil status." ${ }^{13}$ Liah Greenfeld, in a prizewinning (though controversial) book published in 2001, took this further and argued that Britain's "rise was in the nature of a miracle" that is best explained by the fact that "Nationalism first appeared in England ... which it was the only one to possess for some two centuries," and this appearance "liberated natural economic energies from the constraining tutelage of ethical considerations and social concerns, and therefore . . . did not inhibit economic growth." 14

Such views of nationhood tend to focus upon England or to elide distinctions between England and Britain. Moreover, while Colley has shown some ways in which ideas of Britishness developed after 1707, Graeme Morton has illustrated the danger that "Whiggish principles of state formation have masked national tensions which have never yet been eradicated." 15 There was plenty of evidence

${ }^{11}$ Paul Langford, "Introduction: Time and Space," in The Eighteenth Century: 1688-1815, ed. Paul Langford (Oxford, 2002), 9; Giorgio Riello and P. K. O'Brien, "Reconstructing the Industrial Revolution: Analyses, Perceptions and Conceptions of Britain's Precocious Transition to Europe's First Industrial Society," LSE Working Papers in Economic History 84/04 (London School of Economics and Political Science, Department of Economic History, London, 2004); Josephine Grieder, Anglomania in France, 1740-1789: Fact, Fiction, and Political Discourse (Geneva, 1985); François Crouzet, Britain Ascendant: Comparative Studies in Franco-British Economic History (Cambridge, 1990), chap. 4; Robert Tombs and Isabelle Tombs, That Sweet Enemy: The French and the British from the Sun King to the Present (New York, 2006), 84.

${ }^{12}$ Herbert Butterfield, The Whig Interpretation of History (London, 1931). English ideas of their national exceptionalism were reasonably well developed by 1600; surveyed in Keith E. Wrightson, "Kindred Adjoining Kingdoms: An English Perspective on the Social and Economic History of Early Modern Scotland," in Scottish Society, 1500-1800, ed. R. A. Houston and I. D. Whyte (Cambridge, 1989), 246-50.

${ }^{13}$ David S. Landes, The Wealth and Poverty of Nations: or Why Some Are So Rich and Some So Poor (New York, 1998), 219.

${ }^{14}$ Liah Greenfeld, The Spirit of Capitalism: Nationalism and Economic Growth (Cambridge, MA, 2001), 22-24. Greenfeld considers English nationalism but British economic performance. There is a fine critical review of this book by Andre Wakefield in the Journal of Modern History 75, no. 4 (December 2003): 926-28. See also Liah Greenfeld's Nationalism: Five Roads to Modernity (Cambridge, MA, 1992).

${ }^{15}$ Colley, Britons; Graeme Morton, Unionist-Nationalism: Governing Urban Scotland, 1830-1860 (East Linton, 1999), 4. 
in the eighteenth century of such tensions, but some also noted differences in the intensity of national identity across the three kingdoms. In 1750, for example, Sir James Lowther believed that the Irish and the Scotch "are both more national than the English."16 After 1707 many English and Scots had different ideas of what Britain was: most Scots saw themselves as both Scottish and British, but most English made little distinction between England and Britain. ${ }^{17}$ No less importantly, Ireland, both as "other" and then, from 1801, as part of the United Kingdom, further muddied the waters of national identity in Britain. Nationhood and national identity in Britain have been so uncertain since at least the seventeenth century that they are not concepts that can be employed to understand the emergence of the first industrial revolution in any reasonably testable way.

A second conventional argument about the national exceptionalism of the first industrial revolution has considered the implications of constitutional developments, along two main lines. At the most general level there are views such as Thomas Sowell's that Britain's early economic transformation happened when it did because Britain had established before almost everywhere else "a framework of law and government that facilitated economic transactions," particularly by pioneering the establishment of "freedom." ${ }^{18}$ Yet, as David Armitage has noted, "Though it has been argued that the Glorious Revolution represented the victory of law, liberty and localism against absolutism, subordination and centralisation, this perspective is only true of England and, possibly, the American mainland colonies." ${ }^{19}$ The politics and teleology behind arguments such as Sowell's are highlighted in Gordon Brown's identification of a "golden thread" of liberty running through British history, as well as the view of the then recently retired Chairman of the Federal Reserve, Alan Greenspan, that the most "free" of the leading modern economies "all have roots in Britain." ${ }^{20}$ Such views bring to mind Condorcet's warning of the dangers of circular reasoning, whereby "liberty will be no more, in the eyes of an avid nation, than the necessary condition for the security of financial operations." 21

The second line of constitutional exceptionalism has emphasized how the Glorious Revolution led to a more powerful state that was better able to protect and project the nation's interests, while securing property rights at home in ways

\footnotetext{
${ }^{16}$ Quoted in Christopher A. Whatley, Scottish Society, 1707-1830: Beyond Jacobitism, Towards Industrialization (Manchester, 2000), 118.

${ }^{17}$ T. C. Smout, "Problems of Nationalism, Identity and Improvement in Later Eighteenth-Century Scotland," in Improvement and Enlightenment, ed. T. M. Devine (Edinburgh, 1989), 5-8. See also the works cited in n. 3 above.

${ }^{18}$ Thomas Sowell, Conquests and Cultures: An International History (New York, 1998), 32, 87. Similarly, Douglass C. North, "The Paradox of the West," in The Origins of Modern Freedom in the West, ed. R. W. Davis (Stanford, CA, 1995), 8.

19 David Armitage, "The Political Economy of Britain and Ireland after the Glorious Revolution," in Political Thought in Seventeenth Century Ireland: Kingdom or Colony, ed. Jane Ohlmeyer (Cambridge, 2000), 231-32.

${ }^{20}$ Brown noted this "golden thread" through British history since Magna Carta in speeches in 2006 and 2007. It is restated in his introduction to Gertrude Himmelfarb, The Roads to Modernity: The British, French and American Enlightenments (London, 2008), xii. A critical view of Brown's motives is in Tom Nairn, Gordon Brown: Bard of Britishness (Cardiff, 2006). Alan Greenspan, The Age of Turbulence: Adventures in a New World (New York, 2007), 276.

${ }^{21}$ Quoted in Emma Rothschild, "Condorcet and the Conflict of Values," Historical Journal 39, no. 3 (September 1996): 684.
} 
conducive to capitalist enterprise. ${ }^{22}$ For example, in an article that has been very influential among some economic historians, economists, and political scientists, D. C. North and Barry R. Weingast argue that the Glorious Revolution firmly established property rights and balanced the interests of crown and parliament. This led to the transformation of public finances, allowing Britain to rise as France fell, so that "in 1765 France was on the verge of bankruptcy while England was on the verge of the Industrial Revolution." ${ }^{23}$ In a similar vein, Niall Ferguson has argued that Britain led the way in providing the best institutional arrangements for the accumulation of power and wealth: "It was in the eighteenth century that the British state developed the peculiar institutional combination of bureaucracy, parliament, debt and bank that enabled Britain at once to empire-build and to industrialize. $" 24$

Such approaches operate at a fairly high level of generalization, being concerned with governmental measures only and are usually untroubled by whether the experiences of England and Britain were one and the same under the revolution constitution. On this latter point historians of Ireland and Scotland have naturally been more inquisitive, exploring the implications for economic development in those nations of the union of crowns of 1603 and, more particularly, the parliamentary unions of 1707 and 1801. Such approaches have particularly considered the consequences of the level and conditions of access to English or British domestic and imperial markets before and after the unions, including the protection afforded by British armed forces. These considerations are commonly weighed against the importance of factors endogenous to Scotland and Ireland, including the survival after union of institutions distinctive to both. ${ }^{25}$ This article builds upon such approaches by looking at patterns of parliamentary legislation that directly related to the economy. But it is important to begin by recalling some broad

${ }^{22}$ Such arguments build upon major studies of the growth of the British state's power dating back to Dickson. P. G. M. Dickson, The Financial Revolution in England: A Study in Public Credit, 1688-1756 (London, 1967); Peter Mathias and P. K. O’Brien, "Taxation in Britain and France, 1715-1810: A Comparison of the Social and Economic Incidence of Taxes Collected for the Central Government," Journal of European Economic History 5, no. 3 (Winter 1976): 601-50; Brewer, Sinews of Power; N. A. M. Rodger, The Command of the Ocean: A Naval History of Britain, 16491815 (London, 2004).

${ }^{23}$ D. C. North and Barry R. Weingast, "Constitutions and Commitment: The Evolution of Institutions Governing Public Choice in Seventeenth-Century England," Journal of Economic History 49, no. 4 (December 1989): 830-31. They acknowledged, at $804 \mathrm{n}$. 1, that since they emphasize "the problems the winners (the Whigs) sought to solve, it necessarily contains strong elements of 'Whig' history."

${ }^{24}$ Niall Ferguson, The Cash Nexus: Money and Power in the Modern World, 1700-2000 (London, $2001), 20$.

${ }^{25}$ For recent views of Scotland: Whatley, Scottish Society, especially chap. 3; T. M. Devine, "The Modern Economy: Scotland and the Act of Union," in The Transformation of Scotland: The Economy since 1700, ed. T. M. Devine, C. H. Lee, and G. C. Peden (Edinburgh, 2005), 13-33. The economic context of the Union negotiations have long been emphasized. See the references in two recent major interpretations: C. A. Whatley and Derek J. Patrick, The Scots and the Union (Edinburgh, 2006); Allan I. Macinnes, Union and Empire: The Making of the United Kingdom in 1707 (Cambridge, 2007). For a penetrating review of these, see Bob Harris, "The Anglo-Scottish Treaty of Union, 1707 in 2007: Defending the Revolution, Defeating the Jacobites," Journal of British Studies 49, no. 1 (January 2010): 28-46. On Ireland, see L. M. Cullen, An Economic History of Ireland since 1660 (London, $1972)$. 
Table 1-Population Size in Britain and Ireland, 1700-1851

\begin{tabular}{lrrrrr}
\hline & England & Ireland & Scotland & Wales & Total \\
\hline Population (millions): & & & & & \\
$\quad$ 1700 & 5.0 & 1.8 & 1.1 & .4 & 8.3 \\
1801 & 8.4 & 5.2 & 1.6 & .6 & 15.8 \\
1851 & 16.9 & 6.6 & 2.9 & 1.0 & 27.4 \\
Compound annual rate of growth: & & & & & \\
$\quad$ 1700-1801 & .51 & 1.07 & .40 & .29 & .64 \\
$\quad$ 1801-51 & 1.42 & .46 & 1.18 & 1.25 & 1.12 \\
\% total: & & & & & \\
$\quad$ 1700 & 60.5 & 21.7 & 13.0 & 4.7 & 100.0 \\
$\quad 1801$ & 53.1 & 33.2 & 10.2 & 3.7 & 100.0 \\
$\quad 1851$ & 61.8 & 23.9 & 10.6 & 3.7 & 100.0 \\
Territorial size: & & & & & \\
Acres (millions) & 32.2 & 20.8 & 20.1 & 5.1 & 78.3 \\
\% total & 41.2 & 26.7 & 25.6 & 6.5 & 100.0 \\
Acres per person: & & & & & \\
$\quad$ 1700 & 6.4 & 11.6 & 18.7 & 13.1 & 9.4 \\
$\quad 1801$ & 3.9 & 4.0 & 12.5 & 8.7 & 5.0 \\
$\quad 1851$ & 1.9 & 3.2 & 6.9 & 5.1 & 2.9 \\
\hline
\end{tabular}

Sources.-For populations for England 1700, Scotland 1801 and 1851, and Ireland 1801 and 1851, see B. R. Mitchell, British Historical Statistics (Cambridge, 1988), 7, 11. For England and Wales, 1801 and 1851, see British Parliamentary Papers (BPP), 1852-53, vol. 86; and for the 1851 census of Great Britain, number of inhabitants, see BPP, 1801-51, vol. 2. For Ireland 1700 and Scotland 1700, see R. A. Houston, The Population History of Britain and Ireland, 1500-1750 (Basingstoke, 1992), 29, 30. For Wales 1700, see John Williams, Digest of Welsh Historical Statistics, 2 vols. (Cardiff, 1985), 1:6.

differences in the experience of economic change in Britain and Ireland in the period.

It should be noted that the conventional estimates for economic performance, national income or product, exist for Britain but not, for want of evidence, separately for England, Scotland, and Wales. But an alternative demographic approach that considers changes in population size, urbanization, and the size of the agricultural labor force, powerfully developed by Wrigley, offers a way through this impasse. ${ }^{26}$ Save for England, statistics of population growth and urbanization in Britain and Ireland before the first census in 1801 should be considered as rough estimates or best guesses, but nonetheless, as table 1 shows, the numbers are very suggestive.

England comprises just over 40 percent of the total surface area of Britain and Ireland. Yet, in 1700 it had over 60 percent of the population of those islands, giving it a population density of about twice that of Ireland and Wales and three times that of Scotland. Though the population of all four nations grew in the eighteenth century, about 46 percent of the total growth took place in Ireland.

${ }^{26}$ E. A. Wrigley, "Urban Growth and Agricultural Change: England and the Continent in the Early Modern Period," Journal of Interdisciplinary History 15, no. 4 (Spring 1985): 683-728. 
Table 2-Proportion of National Population in Towns of at Least 10,000 in Britain and Ireland, 1700-1851

\begin{tabular}{lcccr}
\hline & England & Ireland & Scotland & Wales \\
\hline 1700 & 13.4 & 5.3 & 5.3 & .0 \\
1801 & 24.0 & 7.4 & 17.3 & 1.7 \\
1851 & 45.1 & 10.6 & 32.0 & 11.7 \\
\hline
\end{tabular}

Sources.-For England 1700 and 1800, see E. A. Wrigley, People, Cities and Wealth: The Transformation of Traditional Society (Oxford, 1987), 177. For Scotland and Ireland 1700 and 1800, see I. D. Whyte, "Scottish and Irish Urbanisation in the Seventeenth and Eighteenth Centuries: A Comparative Perspective," in Conflict, Identity and Economic Development: Ireland and Scotland, 1600-1939, ed. S. J. Connolly, R. A. Houston, and R. J. Morris (Preston, 1995), 16. For England and Scotland 1851, see Lynn Hollen Lees, "Urban Networks," in The Cambridge Urban History of Britain, ed. Peter Clark (Cambridge, 2000), 3:70. For Ireland 1851, see W. E. Vaughan and A. J. Fitzpatrick, eds., Irish Historical Statistics: Population, 1821-1971 (Dublin, 1978), 3, 28-40. Wales 1700 is a guess on the basis that the largest Welsh town in 1801 was Swansea with 10,117; for Wales 1801 and 1851, see John Williams, Digest of Welsh Historical Statistics, 2 vols. (Cardiff, 1985), 1:62-65.

Strikingly, by the first census of 1801 England and Ireland were equally densely populated, both about two and three times as densely populated as Wales and Scotland, respectively. Over the next half century, the populations of England, Scotland, and Wales each roughly doubled, but terrible famine in Ireland in the 1840 s reversed its growth, though it was still the second most densely populated of the four nations in 1851. Despite significant absolute growth, the share of both Scotland and Wales of the total population of Britain and Ireland was slightly smaller in 1851 than in 1700 .

This picture of demographic change can be refined a little by considering patterns of urbanization (see table 2). ${ }^{27}$ Ireland's exploding population in the eighteenth century was associated with only modest urbanization. In contrast, the less rapid population growth in England and Scotland took place with considerable growth of their great towns and cities. Notably, by 1851 Scotland was the least densely populated of the four nations but the second most urbanized. Wales, however, changed little in the eighteenth century in terms of either total population or its distribution. But in the first half of the nineteenth century, its population doubled, and rapid urbanization had begun.

Such figures of population and its distribution show that the timing and patterns of economic change in Britain and Ireland varied from nation to nation-and, of course, from region to region, though there is not room here to develop that analysis. In the context of the concerns of this article, the contrast in the eighteenth century between Ireland and Wales is worth noting. Ireland's population grew vigorously, but that of Wales did not. Ireland urbanized somewhat, Wales hardly at all. Without the benefit of hindsight, it might be wondered which economy was the more vibrant in 1800. Similarly, it is clear that English and Welsh economic development took very different paths before 1801, despite the two nations sharing

\footnotetext{
${ }^{27}$ The threshold of 10,000 persons for a town used here is, of course, a high one, and somewhat different patterns might be uncovered if lower thresholds were used.
} 
the same government. How, then, did parliaments legislate for economic change across all four nations between 1660 and 1800?

Building upon earlier work done partly in collaboration with Joanna Innes, counts of numbers and types of legislation are used to begin to explore the relationship between the state and the economy. It is easy enough to identify the 18,761 acts passed by the parliaments at Edinburgh from 1660 to 1707 and at Dublin and Westminster from 1660 to $1800 .{ }^{28}$ Most acts can also be categorized in terms of subject matter or where they were to apply, not least because most were so specific, not that there is one agreed way of categorizing the subject matter of acts, and some acts might straddle categories. Additionally, the true meanings of others might require more research than has been undertaken. ${ }^{29}$ Furthermore, interpreting counts produced within any given categorization may not be straightforward. Joel Hurstfield nicely hinted at the dangers when questioning G. R. Elton's enumeration of Thomas Cromwell's legislative fertility under Henry VIII when he observed that "I am myself reluctant to attempt to measure the quality of parliamentary government by weight." ${ }^{30}$ Of course, one act might be momentous, the other fairly trivial. Plainly acts such as the 1689 Corn Law were significant in ways in which a private estate act never was, but by keeping this in view, there are meaningful patterns that can be identified that help to shed distinctive light on the relationship in Britain (and Ireland) between parliaments and the economy, of its multifaceted nature and the extent of national variation within Britain. Initially those findings are presented in a largely descriptive way; the following section then seeks to explain the findings and tease out their significance.

Unquestionably, Westminster's capacity to enact legislation expanded dramatically after 1688, indeed, to an extent that is still underappreciated. ${ }^{31}$ In the ten parliamentary sessions before then only 10 percent of attempts to obtain an act succeeded. Thereafter regular, predictable, much better-ordered sessions saw the success rate change profoundly, so that for most of the eighteenth century it was around 75 percent. This contributed to an explosion in the numbers of enactments. In the previous 200 years some 2,700 acts had been passed. In the period between

\footnotetext{
${ }^{28}$ For acts passed at Dublin, see The Statutes at Large, Passed in the Parliaments Held in Ireland, 21 vols. (Dublin, 1786-1804). Short titles of both public and private acts prior to 1799 are listed in the index volume, vol. 8. Private acts for 1799 and 1800 have been taken from Journals of the House of Commons of . . Ireland, vols. 18-19 (1796-1800). For Edinburgh, see The Acts of the Parliaments of Scotland, 12 vols. (Edinburgh, 1820-75). Sources for acts passed at Westminster are Statutes at Large, ed. Owen Ruffhead, 18 vols. (London, 1769-1800). Research for this article was undertaken before the completion of both the Irish Legislation Database at http://www.qub.ac.uk/ild/ and the Records of the Parliaments of Scotland Prior to 1707 at http://www.rps.ac.uk/.

${ }^{29}$ Because of the numbers involved, most acts have been categorized on the basis of their short title. For some questions about the categories employed, see Henry Horwitz, "Changes in the Law and Reform of the Legal Order: England (and Wales) 1689-1760," Parliamentary History 21, no. 3 (November 2002): 314-15.

${ }^{30}$ Joel Hurstfield, Freedom, Corruption and Government in Elizabethan England (London, 1973), 32 .

${ }^{31}$ Julian Hoppit, "Patterns of Parliamentary Legislation, 1660-1800," Historical Journal 39, no. 1 (March 1996): 109-31; Julian Hoppit, ed., Failed Legislation, 1660-1800, Extracted from the Commons and Lords Journals (London, 1997).
} 
Table 3-Main Subject Matter of Westminster Acts, 1660-1800, with Proportion Designated "Specific"

\begin{tabular}{lrrrr}
\hline & General & Specific & Total & \% Specific \\
\hline Personal & 11 & 2,828 & 2,839 & 100 \\
Government & 337 & 1,357 & 1,694 & 80 \\
Finance & 1,434 & 136 & 1,570 & 9 \\
Law and order & 414 & 155 & 569 & 27 \\
Religion & 117 & 256 & 373 & 69 \\
Armed services & 504 & 32 & 536 & 6 \\
Social issues & 131 & 578 & 709 & 82 \\
Economy & 825 & 2,453 & 3,278 & 75 \\
Communications & 107 & 2,486 & 2,593 & 96 \\
Miscellaneous & 47 & 9 & 56 & 16 \\
\multicolumn{1}{c}{ Total } & 3,927 & 10,290 & 14,217 & 72 \\
\hline
\end{tabular}

1688 and union with Ireland in 1801, over 13,600 acts were passed, marking a rise from an average of under 15 per annum to an average of over 290 per annum in the $1790 \mathrm{~s}$, or a nearly twentyfold increase.

The eighteenth century was an era of unprecedented and extraordinary legislative fruitfulness at Westminster, but how much did all this legislation weigh? This can be approached by trying to assess what each act broadly attempted to do in terms of place, subject, and scope. For the last of these criteria acts have been distinguished between those that appear to have applied across at least one of the four nations (classed as general) and those of more limited scope, very largely relating to individuals and particular places (classed as specific). As in all such schemes, some cases straddle the divide, but these are very few in number. (The formal contemporary distinction between public and private legislation inconsistently reflected the scope of legislation and so is not used here.)

Between 1660 and 1800 Westminster passed 14,217 acts. Nearly 28 percent of these can be classed as general, 72 percent as specific. In fact, the Glorious Revolution led to the growth of all types of acts but particularly of acts that were limited in their reach, the proportion of these rising from 64 percent between 1660 and 1688 to 73 percent thereafter. This is a vital distinction, but it needs to be explored in relation to the subject matter of acts. To do this, each act has been placed within one of ten major categories (themselves resting on many more subcategories). ${ }^{32}$

As table 3 shows, three categories accounted for a little over six out of ten of all acts passed in the period: personal, communications, and the economy. As will become clear, all three of these affected economic matters, with only the "finance" category among the others potentially doing so, mainly because of public finance measures. Crucially, legislation classed as "personal," "communications," and "the economy" was overwhelmingly specific rather than general in scope.

Personal acts were dominated by two main types: those dealing with wealth, which almost always concerned issues surrounding land ownership, such as marriage or strict settlements, numbering almost 3,000, and those dealing with status,

${ }^{32}$ The full categories are listed in Hoppit, Failed Legislation, 30-32. 
such as naturalization and dignities, numbering a little over 1,100. Economy acts were similarly dominated by landownership; in this case, enclosure. Over 2,300 economy acts dealt with land issues, and a little over 500 concerned overseas trade, but fewer than 500 addressed the other six subcategories combined. In the communications category, there were nearly 2,000 road acts, usually relating to turnpikes, and over 600 relating to inland navigation, river improvement, and canals.

Four main points might be made about these general counts of Westminster enactments between 1660 and 1800. First, specific economic interests secured an unprecedented number of acts to aid their ambitions after 1688. Parliament provided vital authority, especially to reorder or redefine property rights and improve the infrastructure. ${ }^{33}$ Second, in a number of areas Westminster rarely legislated generally. For example, it passed separate acts for each of the more than 2,000 enclosures it endorsed, not a general enabling one that could serve in all instances. Such measures were largely initiated by individuals or local bodies, motivated largely by self-interested considerations, though they might be legitimated by reference to the national good in ways similar to those social measures analyzed by Innes. ${ }^{34}$ Also important was that executive government rarely developed measures dealing directly with either agriculture or industry-the Corn Laws and some attempts at regulation were the main efforts. ${ }^{35}$ With regard to the economy, only in the area of imperial trade, with the navigation acts, was there something that approximated a policy or system. ${ }^{36}$ In part this was because few contemporaries would contemplate a more interventionist state domestically, but most would countenance closer regulation of overseas trade by the customs service and Royal Navy. Parliament would respond to proposals to enhance economic opportunities, but relatively few such proposals were governmental. The third key point is related to this last observation. As historians from the Webbs onward have shown, parliament created a huge number of local bodies or agencies in the eighteenth century, not only for roads and enclosure but for the poor law, health care, charities,

\footnotetext{
${ }^{33}$ See Julian Hoppit, “The Landed Interest and the National Interest, 1660-1800," in Parliaments, Nations and Identities in Britain and Ireland, 1660-1850, ed. Julian Hoppit (Manchester, 2003), 83102; Dan Bogart and Gary Richardson, "Making Property Productive: Reorganizing Rights to Real and Equitable Estates in Britain, 1660-1830," European Review of Economic History 13, no. 1 (April 2009): 3-30; William Albert, The Turnpike Road System in England, 1663-1840 (Cambridge, 1972); Eric Pawson, Transport and Economy: The Turnpike Roads of Eighteenth-Century Britain (New York, 1977).

${ }^{34}$ Joanna Innes, Inferior Politics: Social Problems and Social Policies in Eighteenth-Century Britain (Oxford, 2009), chap. 1.

${ }^{35} 1$ William and Mary, c. 12 was the foundational statute for the eighteenth-century Corn Laws, though based on earlier, lapsed, legislation; see D. G. Barnes, A History of the English Corn Laws (London, 1930). The textile industries were subject to a range of regulation via legislation. Much of it is listed in Raymond L. Sickinger, "Regulation or Ruination: Parliament's Consistent Pattern of Mercantilist Regulation of the English Textile Trade, 1660-1800," Parliamentary History 19, no. 2 (June 2000): 211-32.

${ }^{36}$ Surveyed in Kenneth Morgan, "Mercantilism and the British Empire, 1688-1815," in The Political Economy of British Historical Experience, 1688-1914, ed. Donald Winch and P. K. O'Brien (Oxford, 2002), 165-91.
} 
education, the urban infrastructure, and so on. ${ }^{37}$ Again, this was almost always done on a case-by-case basis, and even though these efforts might be short-lived or time limited, they significantly enriched and complicated the nature of local governance. A centralized fiscal-military state was brought to fruition after the Glorious Revolution, but there was also a substantial change in the architecture of authority locally. Finally, some of this legislation, such as that concerning turnpikes and enclosure, involved compelling people to sell property and could take away or alter the use rights of local people, making them more dependent upon the market economy. Those people affected may have doubted that what they judged as their property rights had become more secure. ${ }^{38}$

Where did this legislation apply? ${ }^{39}$ Nearly two-thirds of acts gave a clear indication of their geographical scope-ranging from particular buildings to nations and portions of empire. Of those that did not, rather more were, in absolute terms, general than specific in scope. Relatively, however, 70 percent of general acts did not make their reach explicit in their titles, whereas only 23 percent of specific acts were similarly vague. Presumably most of the unspecified general acts affected the whole of England and Wales before 1707 and the whole of Britain thereafter. While some acts did purport to affect only England or Scotland or Wales, numbers were never great, and the distinctions between England and Wales are compromised by sloppy draftsmanship before 1746 when it was enacted that with regard to "England ... the same has been and shall henceforth be deemed and taken to comprehend and include the dominion of Wales, and town of Berwick upon Tweed." ${ }^{40}$ Consequently, at this stage it is much more meaningful to pursue the topic of the national patterns of acts passed at Westminster by focusing upon specific legislation only. I return to legislation that might be considered British in scope later.

The evidence in table 4 is complicated a little by the large number of specific acts that have not been placed within a geographical category. Often these related to particular individuals, as with those concerning naturalization or estates. Detailed work could doubtless allow many to be categorized, but probably the overwhelming majority would be placed within "England." With this caveat in mind, the meaning of table 4 needs little elaboration. Local and personal interests in England obtained legislation at Westminster in very much greater numbers than those in Scotland or Wales (or Ireland).

The position of Wales is worth pondering, given that its government was so similar to that of England after the abolition of the Council of Wales and the Marches in 1689. Westminster passed 192 acts clearly relating only to Wales or

${ }^{37}$ Sidney Webb and Beatrice Webb, English Local Government from the Revolution to the Municipal Corporation Act: Statutory Authorities for Special Purposes (London, 1922); Paul Langford, Public Life and the Propertied Englishman, 1688-1798 (Oxford, 2001); Stuart Handley, "Local Legislative Initiatives for Economic and Social Development in Lancashire, 1689-1731," Parliamentary History 9, no. 1 (March 1990): 14-37; Innes, Inferior Politics, chap. 3.

${ }^{38}$ I address the question of the security of property rights in Julian Hoppit, "Compulsion, Compensation and Property Rights in Britain, 1688-1833," Past and Present, no. 210 (2011): 93-128.

${ }^{39}$ This question has been well explored in Joanna Innes, "Legislating for Three Kingdoms: How the Westminster Parliament Legislated for England, Scotland and Ireland, 1707-1830," in Hoppit, Parliaments, Nations and Identities, 15-47.

${ }^{40} 20$ George II, c. $42, \$ 3$. 


\begin{tabular}{|c|c|c|}
\hline & Total & $\%$ \\
\hline England & 7,189 & 69.9 \\
\hline Ireland & 196 & 1.9 \\
\hline Scotland & 304 & 3.0 \\
\hline Wales & 184 & 1.8 \\
\hline British Empire & 27 & .3 \\
\hline Other & 19 & .2 \\
\hline Not stated & 2,371 & 23.0 \\
\hline Total & $\overline{10,290}$ & 100.1 \\
\hline
\end{tabular}

parts thereof between 1660 and 1800. Of these just eight were general in scope: six related to issues of law and order and two to government. (Governmental measures usually applied to England and Wales or to Britain.) That is, almost all legislation classed as Welsh was specific in scope and the response to applications made by the propertied. Only fifty-one such specific acts were passed between 1660 and 1760, but in the final forty years of the eighteenth century 133 were passed. That growth was overwhelmingly caused by heightened numbers of acts for communications and the economy. Before 1760 they accounted for only 14 percent of all acts relating to parts of Wales (71 percent of such acts were personal); after 1760 they accounted for 82 percent. But whereas for England between 1760 and 1800 the volume of enclosure legislation surpassed that for turnpikes, in Wales the reverse was true, albeit at very much lower levels. ${ }^{41}$ Some possible explanations for this are offered later.

Even more than Wales, relative to population, Scottish specific interests secured remarkably few acts at Westminster between 1707 and 1800. As shown above, in this period England's population was about five times that of Scotland, but its specific interests obtained over twenty-three times more legislation than those of Scotland. Previously, however, specific Scottish interests had obtained legislation from the Edinburgh parliament much more frequently. Between 1660 and union in 1707 the Edinburgh parliament was highly active, passing over 2,200 acts, compared to nearly 1,900 at Westminster in the same period, only three of which related to Scotland. Given Scotland's small population and lack of colonies or empire, this hints that legislation played a somewhat different role north and south of the border before 1707. In Scotland, even more than England and Wales, it was often extremely particular in complexion. Nonetheless, though nearly threequarters of the legislation was specific in scope, the Glorious Revolution led to an important change in the pattern, as table 5 shows.

The average annual rate of legislation passed at Edinburgh remained steady on either side of the revolution, but after 1688-89 significantly more of it was general in scope-a rise from an annual average of eleven to seventeen acts-and there was also a steep decline both absolutely and relatively in numbers of personal legislation, falling from nearly one-third to under one-fifth of legislation. This was

${ }^{41}$ It should be noted that turnpikes were usually authorized for twenty-one years, requiring new legislation to extend their lives. 
Table 5-Number of Edinburgh Acts, by Scope, 1660-1706

\begin{tabular}{lccc}
\hline & General & Specific & \% Specific \\
\hline $1660-88$ (29 years) & 319 & 1,069 & 77 \\
$1689-1706$ (18 years $)$ & 321 & 508 & 61 \\
\hline
\end{tabular}

a very different pattern from that at Westminster, as table 6 shows. The parliament at Edinburgh had been more closely controlled by the executive before the revolution, but once that weakened, thereafter legislators were better able to address more general matters, including establishing a standing committee for trade. ${ }^{42}$ By subject matter, almost all types of acts became more general and less specific. However, while numbers of acts relating to the economy grew more quickly than for any other subject after 1688, the change to more general legislation was less marked. Before then there were 254 acts in this category, with 14 percent of them general. Afterward there were 231 acts, some 20 percent of them general. The particular driver here was obtaining acts to regulate local markets. There is no denying the legislative fecundity of the Edinburgh parliament in this period and that there were significant changes in the nature of what was enacted. Yet, despite this, the Edinburgh parliament was voted out of existence. ${ }^{43}$

A significant number of Scots had been in favor of the union, largely on the economic grounds that it would remove almost all barriers to doing business across England and its empire. ${ }^{44}$ This benefit they gradually came to exploit to the full. But importantly, in the eighteenth century they rarely turned to Westminster to provide further legislative underpinnings to bring about change, certainly less often than might have been expected. Of legislation passed at Westminster from 1707 to 1800 , which made clear its local, regional, or national relevance, only 464 acts, or under 6 percent, related only to Scotland as a whole or in part- 160 general

Table 6-Comparison of Legislation at Edinburgh and Westminster, 1660-1707

\begin{tabular}{lcc}
\hline & $1660-88$ & $1689-1707$ \\
\hline Edinburgh acts, annual average & 47.9 & 46.1 \\
Westminster acts, annual average & 19.4 & 72.1 \\
Edinburgh acts, \% general & 23.0 & 38.7 \\
Westminster acts, \% general & 36.3 & 31.6 \\
\hline
\end{tabular}

${ }^{42}$ Keith M. Brown and A. J. Mann, "Introduction," in The History of the Scottish Parliament, ed. Keith M. Brown, 3 vols. (Edinburgh, 2004-10), 2:52.

${ }^{43}$ Generally, see Brown, The History of the Scottish Parliament, vol. 2; C. S. Terry, The Scottish Parliament: Its Constitution and Procedure, 1603-1707 (Glasgow, 1905).

${ }^{44}$ In addition to the works cited in n. 25 above, see also T. C. Smout, "The Anglo-Scottish Union, 1707, 1: The Economic Background," Economic History Review 16, no. 3 (April 1964): 455-67; C. A. Whatley, "Economic Causes and Consequences of the Union of 1707: A Survey," Scottish Historical Review 68, no. 2 (October 1989): 150-81; T. M. Devine, "The Union of 1707 and Scottish Development," Scottish Economic and Social History 4 (1984): 23-40. 
Table 7-Number of Dublin Acts, by Scope, 1660-1800

\begin{tabular}{lrrrr}
\hline & General & Specific & \% Specific & Total \\
\hline $1660-88$ & 41 & 17 & 29 & 58 \\
$1689-1714$ & 140 & 74 & 35 & 214 \\
$1714-60$ & 330 & 186 & 36 & 516 \\
$1760-82$ & 302 & 183 & 38 & 485 \\
$1782-1800$ & 788 & 266 & 25 & 1,054 \\
\multicolumn{1}{c}{ Totals, 1660-1800 } & 1,601 & 726 & 31 & 2,327 \\
\hline
\end{tabular}

acts, 304 specific. ${ }^{45}$ Under the revolution constitution, the Edinburgh parliament passed an average of forty-six acts per year, but between 1707 and 1800 there were only five per year addressing exclusively Scottish matters-though some of the many "not stated" would also have done so but probably not in any great number.

If legislation relating to Scotland shrank dramatically after the union, there are nonetheless some other general points to be made. First, while a little more of this was specific rather than general in scope compared to that passed at Edinburgh before the union, there was still relatively more general legislation than that passed at Westminster as a whole (one-third compared to one-quarter). Moreover, the subject matter involved was more widely distributed than for England. Crucially, Scottish landowners did not turn to Westminster for legislation to reorder or enclose their estates: only to undertake urban and infrastructural improvement did Scottish interests seek acts at Westminster with any frequency.

A comparison can now usefully be made between the legislative activities of the Dublin and Westminster parliaments. ${ }^{46}$ As in England and Scotland, from one perspective Ireland's parliament was energized by the Glorious Revolution. Having passed only 58 acts between 1660 and 1666, it did not meet again until the revolution, thereafter usually meeting biennially. This enabled it to pass over 2,200 acts before union in 1801, a huge increase, but only about one-sixth the number passed at Westminster, even though in 1800 Ireland's population was nearly onehalf that of Britain's.

Unsurprisingly, there were important differences in the character of legislation passed at Dublin and Westminster. As table 7 shows, at Dublin general legislation purporting to affect the whole island, or very large parts of it, predominated, accounting for 69 percent of acts passed between 1689 and 1800, whereas just 27 percent of acts passed at Westminster were general. Most legislation passed in Dublin in this period was, therefore, much more governmental in nature, relating to public finance; the economy, particularly overseas trade; and law and order. Put another way, recalling the earlier discussion, at Westminster around 60 percent of

\footnotetext{
${ }^{45}$ A number of historians have stated that Westminster passed only nine acts relating specifically to Scotland between 1727 and 1745; e.g., J. S. Shaw, The Management of Scottish Society, 1707-1764: Power, Nobles, Lawyers, Edinburgh Agents and English Influence (Edinburgh, 1983), 126; Devine, "The Union of 1707 and Scottish Development," 30. It may be that what is meant is that only nine acts related to the whole of Scotland, but twenty-eight acts relating only to Scotland were passed in those years, many of them public and general, and eighty-one acts between 1707 and 1745 .

${ }^{46}$ See also David W. Hayton, "Introduction: The Long Apprenticeship," Parliamentary History 20, no. 1 (February 2001): 1-26.
} 
acts fell under three main headings: personal, economy, and communications. At Dublin these accounted for only 43 percent of acts, and in the case of the economy acts, the subcategory of "the land" accounted for only one in twelve, compared to two out of every three at Westminster. Yet, private economic interests did look to the Dublin parliament for statutes. For example, just as in Britain, acts of the Dublin parliament were used to authorize river and road improvement. ${ }^{47}$ That is to say, there is no reason to suppose that Irish economic interests were unable to get the sorts of specific legislation they might have wanted. Indeed, arguably they could obtain legislation more easily than their Scottish counterparts.

Between 1660 and 1800 the parliaments of Britain and Ireland passed 18,761 acts, with nearly 90 percent of this legislation occurring after the Glorious Revolution. Westminster accounted for nearly 76 percent of all legislation passed by the three parliaments, but both the Edinburgh and Dublin parliaments were notably active between 1688 and their abolitions. Yet, little legislation passed at Westminster in the eighteenth century dealt with Scotland or Wales, while the legislation passed at Dublin was far more general in scope. Put most simply, specific propertied interests in England sought legislation in much greater numbers than such interests in the other three nations, even when allowance is made for differences in population and territorial size.

Part of the explanation for this lies in the relative significance of propertied interests across the four nations. ${ }^{48}$ Because England's economy was much larger and better developed, it had many more interests that might seek legislation to further their ambitions than in the other three nations: demand was both absolutely and relatively greater. For example, there is no reason to suppose that propertied interests in Wales were reluctant to seek legislation at Westminster. They had local MPs available to help them, and, unlike Ireland and Scotland, Wales was not seen as a threat by the English. That is, the relatively low numbers of acts relating specifically to Wales, and their distribution over time and by subject, likely reflected the nature of the Welsh economy and the production of opportunities and problems that the propertied might have sought to exploit or solve via legislation. The most significant explanation is that much land in Wales was already enclosed because of the greater relative extent of pastoral agriculture. Moreover, pastoralism perhaps afforded fewer opportunities to develop rural domestic industries (helping to account for the lower population density in Wales) and, thereby, created less pressure for interregional trade and infrastructural improvement. ${ }^{49}$ Only much later than in England did Welsh roads begin to look in need of improving via turnpikes.

\footnotetext{
${ }^{47}$ Ruth Delaney, Ireland's Inland Waterways(Belfast, 1986); David Broderick, The First Toll Roads: Ireland's Turnpike Roads, 1729-1858 (Cork, 2002).

48 "Propertied interests" is obviously a catchall term, including owners of land, businesses, and rights, but there is not space here to differentiate them nor to consider the various ways they sought to attain their ends.

${ }^{49}$ Frank Emery, "Wales," in The Agrarian History of England and Wales, ed. Joan Thirsk, 8 vols. (Cambridge, 1967-2000), 5, pt. 1:393-428. The suggestions in Giraldus Cambrensis, Proposals for Enriching the Principality of Wales: Humbly Submitted to the Consideration of his Countrymen (London, 1755), were wholly for improving agriculture. Industry was ignored.
} 
Wales's position under the revolution constitution was no different to that of England, but, because of the nature of its society and economy, it was unable to exploit the benefits of parliament's greater accessibility after 1688 until very much later.

Such factors can clearly also be extended to Ireland and Scotland, for in very general terms both economies were less successful than England's. But other considerations may also have been at work in the Scottish case. Four important reasons for the seemingly hesitant use by Scots of the Westminster parliament after 1707 might be emphasized. First, the English showed relatively little interest in governing Scotland after the union, and indeed, except for matters of security, tended to neglect it. ${ }^{50}$ This suited many propertied interests north of the border, who were happy with such semi-independence or "salutary neglect." 1 Second, the Scottish were distant from and a minority at Westminster. It was more difficult and costly for them to use it than their English or Welsh counterparts, and perhaps they were less optimistic about legislative proposals being heard sympathetically. Third, and closely related, in certain areas they had less need to request legislation because there were authorities more easily to hand, specifically the Convention of the Royal Burghs, the General Assembly of the Church of Scotland, and the Court of Session. So, for example, the Convention of the Royal Burghs, a representative assembly for dozens of towns and cities in Scotland, which, despite enjoying considerable trading privileges, had been in decline before the union, was somewhat revived thereafter because of its convenience as a forum for the airing of grievances and ambitions and, critically, because it had some teeth-it passed what were called acts. As Harris noted, it "constituted a national lobbying body for Scottish economic interests of considerable scope and sophistication." 52 Perhaps by providing such a focal point and being willing to engage with executive government in London, the convention aided the consolidation of issues, helping thereby to explain the rather higher proportion of legislation relating to Scotland that was general in scope when compared to all Westminster legislation. Finally, Scottish law, which of course continued to be quite separate from English law after the union, sometimes already provided the propertied with what their English counterparts could only dream of. Thus, not a single enclosure act was passed with regard to Scotland between 1707 and 1800-there were over 2,000 for England and Wales-because of the greater power and concentration of Scottish landowners ("Scottish landowners were the most absolute in Britain") and, crucially, because they could use general enclosure acts passed at Edinburgh in the seventeenth

\footnotetext{
${ }^{50}$ The most concerted effort by the government in London to legislate for Scotland followed the failure of the Jacobite rising in 1746. See B. F. Jewell, "The Legislation Relating to Scotland after the '45" (PhD diss., University of North Carolina, 1975). More generally, P. W. J. Riley, The English Ministers and Scotland, 1707-1727 (London, 1964); Shaw, The Management of Scottish Society.

${ }^{51}$ J. A. Henretta, "Salutary Neglect": Colonial Administration under the Duke of Newcastle (Princeton, NJ, 1972).

${ }^{52}$ Theodora Pagan, The Convention of the Royal Burghs of Scotland (Glasgow, 1926); T. Keith, "The Influence of the Convention of the Royal Burghs of Scotland on the Economic Development of Scotland before 1707," Scottish Historical Review 10 (1913): 250-71; Bob Harris, Politics and the Nation, 63, and also "The Scots, the Westminster Parliament, and the British State in the Eighteenth Century," in Hoppit, Parliaments, Nations, and Identities, 124-45.
} 
century. ${ }^{53}$ Both the third and fourth factors here introduce the important consideration that propertied interests could seek state-sanctioned authority from elsewhere than parliament.

In Ireland too there was virtually no enclosure legislation, and levels of legislation were relatively low even though the Dublin parliament continued to legislate until the union with Westminster took effect in 1801. There are obvious enough reasons for this, relating to highly unequal patterns of landownership in Ireland, the strength and extent of the pastoral economy, the restrictions formally in place against the Catholic majority and Presbyterian minority, and, until 1782, the clear subservience of the Dublin parliament to Westminster and Whitehall. Not only under the terms of Poynings's law, dating back to 1495, did legislation proposed at Dublin have to be cleared in London but in 1720 Westminster's Declaratory Act claimed a historic and continuing right to legislate for Ireland. ${ }^{54}$ Westminster had indeed long been doing this and passed over 270 acts relating to Ireland between the revolution and the abolition of the Dublin parliament (compared to just three relating to Scotland between 1660 and 1707). If over a hundred of these were personal acts, probably explained by the Anglo-Irish nature of the landowners involved, most of the remainder related to the governance of Ireland, especially its security and its economy, especially that the Irish economy should not compete with England's. In these two fundamental regards Ireland was seen as a threat at Westminster. Irish cattle and woolens were considered especially dangerous to English interests, leading to their exclusion from England and Wales. ${ }^{55}$ Ireland thus fell under one crown but, unlike the other three nations, two parliaments.

The significance of the volume of specific legislation is not, of course, the whole of the story of the relationship between the nation, the state, and economic change in Britain before 1800. Clearly, some general legislation was vitally important, and some of it was or came to be British. Perhaps this was most true in the area of regulating overseas trade. The Scots were brought within England's empire from 1707, gradually allowing them to forget the Darien catastrophe of less than a decade earlier. The Act of Union was quickly distributed to colonial governors, with instructions that it be strictly observed, though ideas of Britishness were not yet invoked: they were told that "Scotchmen are . . to be looked upon for the

\footnotetext{
${ }^{53}$ The quotation is from T. C. Smout, "Scottish Landowners and Economic Growth, 1650-1850," Scottish Journal of Political Economy 11 (1964): 218; Hoppit, “The Landed Interest," 94-95; T. M. Devine, "The Great Landowners of Lowland Scotland and Agrarian Change in the Eighteenth Century," in Scottish Power Centres from the Early Middle Ages to the Twentieth Century, ed. Sally Foster, Allan Macinnes, and Ranald MacInnes (Glasgow, 1998), 147-61.

${ }^{54}$ James Kelly, Poynings' Law and the Making of Law in Ireland, 1660-1800 (Dublin, 2007); I. Victory, "The Making of the 1720 Declaratory Act," in Parliament, Politics and People: Essays in Eighteenth-Century Irish History, ed. Gerard O'Brien (Dublin, 1989), 9-29.

${ }^{55}$ Carolyn A. Edie, "The Irish Cattle Bills: A Study in Restoration Politics," Transactions of the American Philosophical Society 60, no. 2 (February 1970): 1-66; Hugh F. Kearney, "The Political Background to English Mercantilism, 1695-1700," Economic History Review 11, no. 3 (April 1959): 484-96; P. H. Kelly, “The Irish Woollen Export Prohibition Act of 1699: Kearney Re-visited," Irish Economic and Social History 7 (1980): 22-43.
} 
future as Englishmen to all intents and purposes whatsoever." ${ }^{56}$ Another good example of practical political economy that affected Britain as a whole would be the protection afforded to textile producers by bans on imported printed calicoes. ${ }^{57}$ Other such measures might be cited.

But not all economic legislation that purported to apply across Britain actually did so. As has already been noted, the efficient fiscal-military state depicted by Brewer was English, not British. There is mounting evidence of the extent of evasion well into the second half of the eighteenth century, especially on the coasts of the Irish sea, with the Isle of Man playing a pivotal role until $1765 .^{58}$ Similarly, union may have created the largest free-trade area in Europe, but its requirement that English standards of weights and measures be applied across Britain was often ignored before the introduction of the "imperial system" in 1824. For example, in Scotland corn often continued to be measured not by the Winchester bushel but by the boll, which varied considerably between Scotland's counties. Much the same was true of the "acre." 59 In a related vein, some legislation that was apparently British might particularly favor English or Scottish economic interests (Welsh interests do not appear to have figured in such instances). Bounties provide several telling examples here. Thus, the Corn Laws, made permanent as the first major piece of economic legislation after the Glorious Revolution, were modified at the union to try to offer some benefits to Scotland, but with little success. Over $£ 6$ million were spent on corn export bounties in the eighteenth century, very little of it north of the border. As one informed Scottish commentator noted, "Scotland has hardly been as yet in any respect benefited by the British corn-laws; as these laws have never yet been properly adapted to the nature and circumstances of that part of the island." ${ }^{60}$ Rather, the reverse was true with regard to bounties on fishing, which again the union had sought to equalize across Britain, Anna Gambles noting that "British fisheries legislation seems to have privileged Ireland and Scotland through what amounted to regional fiscal subsidies." area of difference, albeit arguably more social than economic in its implications, was the poor laws. There were well-known distinctions between England and

${ }^{56}$ Calendar of State Papers, Colonial Series, 1706-1708, June, ed. C. Headlam (London, 1916), 42627,431 .

${ }^{57}$ Patrick O'Brien, Trevor Griffiths, and Philip Hunt, "Political Components of the Industrial Revolution: Parliament and the English Cotton Textile Industry, 1660-1774," Economic History Review 44 (1991): 395-423.

${ }^{58}$ F. G. James, "Irish Smuggling in the Eighteenth Century," Irish Historical Studies 12, no. 48 (September 1961): 299-316; L. M. Cullen, Smuggling and the Ayrshire Economic Boom in the 1760s and 1770s (Ayr, 1994); R. C. Nash, "The English and Scottish Tobacco Trades in the Seventeenth and Eighteenth Centuries: Legal and Illegal Trade," Economic History Review 35, no. 3 (August 1982): 354-72; R. M. Stott, "Revolution? What Revolution? Some Thoughts about Revestment," Proceedings of the Isle of Man Natural and Antiquarian Society 11, no. 4 (2003-5): 541-52.

${ }^{59}$ Julian Hoppit, “Reforming Britain's Weights and Measures, 1660-1824," English Historical Review 108, no. 426 (January 1993): 82-104.

${ }^{60}$ Julian Hoppit, "Bounties, the Economy and the State in Britain, 1689-1800," in The Regulation of the Economy, 1660-1850, ed. P. Gauci (forthcoming); J. Anderson, Observations on the means of Exciting a Spirit of National Industry; Chiefly Intended to Promote the Agriculture, commerce, Manufactures, and Fisheries of Scotland (Edinburgh, 1777), 372.

${ }^{61}$ Anna Gambles, "Free Trade and State Formation: The Political Economy of Fisheries Policy in Britain and the United Kingdom, circa 1780-1850," Journal of British Studies 39, no. 3 (July 2000): 292. 
Wales, on the one hand, and Scotland, on the other, with James Anderson judging in this case the advantage to the latter, the poor rates being "a burthensome tax, fraught with many growing evils, which has a natural tendency to enervate industry." ${ }^{2}$ But there was also some variation between parts of Wales and England. In 1770 the assize judges complained (interestingly to the Treasury) that in the counties of Anglesey and Caernavon local magistrates "after our repeated Admonitions, seem determined not to Execute the [Poor] Laws." "63

Such variations sat alongside differences in levels of direct public spending on economic projects. Contemporaries appreciated some of the economic weaknesses of Scotland and Ireland, often feeling that greater public efforts were needed there to compensate for the lack of private enterprise and, in the Irish case, Anglocentric trade regulations. Crucially, the culture of improvement that was reasonably well articulated in England by 1660 came over the next century to exert considerable force in the other three nations. ${ }^{64}$ Selfless and selfish motivations were involved: improvement patriotically sought to make one's country as strong as possible, even if the national origin of the ideas involved was immaterial, while higher rents or profits for individuals increased their chances of status enhancement. In England, the selfish motives were powerful because of reasonably widely diffused private capital that was, where necessary, buttressed by acts of parliament provided by a "reactive state." ${ }^{65}$ As has been seen, this was much less common in Ireland and Scotland, but there the state was more willing and able to employ directly public funds for economic ends.

Scotland received public funds at and after the union to stimulate the domestic economy, funds that came to be particularly directed at the linen and fishing industries. ${ }^{66}$ Article 15 of the union provided $£ 2,000$ annually for seven years to encourage the woolen industry, fisheries, and other manufactures. In 1718 a further annuity of $£ 2,000$ was created, and from 1724 the surplus yield on the malt tax was also to be made available. This prompted the Convention of the Royal Burghs to argue for the funds to be administered by an independent body, leading to the statutory creation of a Board of Trustees for Fisheries and Manufactures

${ }^{62}$ Anderson, Observations, 460.

${ }^{63}$ The National Archives (TNA): Public Record Office (PRO), Tl/487, fol. 314. Joanna Innes, "The Distinctiveness of the English Poor Laws, 1750-1850," in Winch and O'Brien, The Political Economy of British Historical Experience, 381-407; Peter Solar, "Poor Relief and English Economic Development before the Industrial Revolution," Economic History Review 48, no. 1 (February 1995): $1-22$.

${ }^{64}$ Paul Slack, From Reformation to Improvement: Public Welfare in Early Modern England (Oxford, 1999), esp. 80-81; Toby Barnard, Improving Ireland? Projects, Prophets and Profiteers, 1641-1786 (Dublin, 2008); Rosalind Mitchison, "Patriotism and National Identity in Eighteenth Century Scotland," in Nationality and the Pursuit of National Independence, ed. T. W. Moody (Belfast, 1978), 73-95; T. M. Devine, ed., Lairds and Improvement in the Scotland of the Enlightenment (Dundee, 1979); Sarah Tarlow, The Archaeology of Improvement in Britain, 1750-1850 (Cambridge, 2007), 10-18; G. H. Jenkins, The Foundations of Modern Wales: Wales, 1642-1780 (Oxford, 1987), 280.

65 "The Reactive State: English Governance and Society, 1689-1750," in Stilling the Grumbling Hive: The Response to Social and Economic Problems in England, 1689-1750, ed. Lee Davison, Tim Hitchcock, Tim Keirn, and Robert B. Shoemaker (Stroud, 1992), xi-liv.

${ }^{66}$ Central government also spent $£ 169,000$ on roads in 1760-1800, well after their military purpose became secondary. Patrick Colquhoun, A Treatise on the Wealth, Power, and Resources of the British Empire (London, 1814), 228; BPP, 1868-89, 35:448. 
in 1727 , with an initial budget of $£ 6,000$ per annum. ${ }^{67}$ Attention soon focused upon the linen industry, whose fortunes were significantly enhanced with the introduction of an export bounty in 1742 for British linens, in place (with a brief hiatus in the 1750s) until 1832. The board expended $£ 236,000$ on the linen industry and $£ 150,000$ on flax production between 1727 and $1815 .^{68}$ Scotland's linen industry prospered under these stimulants, its output doubling every twenty years from 1730 to $1800 .{ }^{69}$

The considerable attempts to encourage the Scottish fishing industry were rather less successful. Governmental enthusiasm for this trade was very apparent between the restoration and the union, with several acts passed at Edinburgh, though the Royal Fishery Company established in 1670 was dismantled in 1690. In 1711 the Convention of the Royal Burghs and the Board of Trade in London investigated the Scottish fishing industry but to little significant effect. From 1727 the Board of Trustees gave out premiums to encourage the Scottish fisheries but gave this up in 1742 because of the losses incurred. ${ }^{70}$ In 1749 the Free British Fishery Society was created by statute as a public-private venture to try to restart the Scottish fisheries in particular. The society's capital came from private subscriptions, but state bounties were provided to encourage both the building of shipping busses and the export of herring. Initially successful, the society ran into serious difficulties with the advent of war in $1756 .{ }^{71}$ But $£ 647,000$ were spent in bounties for the herring fisheries in Scotland between 1765 and $1796 .^{72}$

Both before and after the union Scottish burghs often gained statutory authority to impose further duties on the sale of beer to help fund urban improvements of various sorts. "Scots burghs, by such means, gained less tightly constricted additions to their disposable funds than English corporations ever did by their local acts." ${ }^{\prime 73}$ Not all such funds were spent on projects to improve local economies, notably markets and infrastructure, but a significant amount appears to have been. Moreover, other sources of public funds might be accessed. Thus, for example, the port of Greenock, developed by Sir John Shaw and opened in 1710 at a cost of $£ 5,555$, was paid for via a local tax on malt for 30 years. ${ }^{74}$

Comparable developments to those in Scotland also took place in Ireland. If Ireland lacked sufficient private capital to lead to a large number of specific acts to aid agricultural and infrastructural change, the public purse was very much fuller, encouraging legislators in Dublin to fund various economic projects, often through direct subsidies. The efforts made via the Linen Board (1711-1828) are the best known of these. Established with funds arising from the excise on tea, it

\footnotetext{
${ }^{67}$ R. H. Campbell, ed., States of the Annual Progress of the Linen Manufacture, 1727-1754 (Edinburgh, 1964), v-vii.

${ }^{68}$ A. J. Durie, The Scottish Linen Industry in the Eighteenth Century (Edinburgh, 1979), 29, 164.

${ }^{69}$ A. J. Durie, The British Linen Company, 1745-1775 (Edinburgh, 1996), 1-5.

${ }^{70}$ Bob Harris, "Scotland's Herring Fisheries and the Prosperity of the Nation, c. 1660-1760," Scottish Historical Review 79, no. 1 (April 2000): 39-60.

${ }^{71}$ Bob Harris, "Patriotic Commerce and National Revival: The Free British Fishery Society and British Politics, c. 1749-1758," English Historical Review 114, no. 456 (April 1999): 285-313.

${ }^{72}$ Report Respecting the British fisheries (1798), 218-25, reprinted in House of Commons Sessional Papers of the Eighteenth Century, ed. Sheila Lambert (Wilmington, DE, 1975), 118:506-13.

${ }^{73}$ Innes, Inferior Politics, 102.

${ }^{74}$ E. J. Graham, A Maritime History of Scotland, 1650-1790 (East Linton, 2002), 319.
} 
also received effectively annual grants from 1721 , totaling $£ 247,340$ by $1800 .^{75}$ The Linen Board was to encourage an industry judged well suited both to Irish conditions and to English interests and, if not entirely successful, was in a way "a remarkably progressive achievement for an eighteenth-century government," an "undeniable triumph." 76 A similarly constituted and funded body to aid river improvement, canal building, and agricultural development began life in 1729, and some $£ 900,000$ of public money was spent on canals by $1787 .{ }^{77}$ Many other grants were also made, proliferating from midcentury. For example, in a two-week period in the autumn of 1755 the Irish House of Commons received fifty petitions seeking "encouragement" for various projects, including twenty-six relating to manufactures and thirteen to infrastructure. Grants totaling $£ 55,800$ were awarded. Moreover, a raft of bounties were also provided to encourage various areas of economic activity. As Conrad Gill nicely put it, "'Parliamentary Colbertism” had become as strong a force in Ireland as in any country in Europe." ${ }^{\prime 8}$ As yet no overall figure is available for the amount of public finance pumped into the domestic Irish economy in the eighteenth century by the Dublin parliament, but it was certainly very substantial, dwarfing what was attempted in England and Scotland. Yet, as Barnard has remarked, "how far into society the benefits reached, may be questioned"; certainly in the end such funds were unable to make up for the lack of private capital. ${ }^{79}$

I have tried in this article to heed S. R. Epstein's cogent warning against projecting "backwards in time a form of centralised sovereignty and jurisdictional integration that was first achieved in Continental Europe in the nineteenth century." ${ }^{80}$ It is, of course, tempting to see nationhood and state formation in Britain between 1660 and 1801 as involving marked consolidation and centralization, with England coming to exercise increasing authority over Ireland, Scotland, and Wales, especially through the efforts of the sovereign parliament after $1688 .{ }^{81}$ Certainly some such developments took place, but, as this article has shown, the Glorious Revolution generated both centrifugal and centripetal forces. The legislative activity of all three parliaments of the four nations was significantly invig-

${ }^{75}$ T. J. Kiernan, History of the Financial Administration of Ireland to 1817 (London, 1930), 16579; Harry Gribbon, "The Irish Linen Board, 1711-1828," in The Warp of Ulster's Past, ed. Marilyn Cohen (Basingstoke, 1997), 71-91.

${ }^{76}$ Edith Mary Johnston-Liik, History of the Irish Parliament, 1692-1800, 6 vols. (Belfast, 2002), 1: 307; Barnard, Improving Ireland? 168.

77 Toby Barnard, The Kingdom of Ireland, 1641-1760 (Basingstoke, 2004), 88; E. Magennis, “Coal, Corn and Canals: Parliament and the Dispersal of Public Moneys 1695-1772," Parliamentary History 20, no. 1 (February 2001): 74.

${ }^{78}$ Magennis, "Coal, Corn and Canals," 81; Conrad Gill, The Rise of the Irish Linen Industry (Oxford, $1925), 197$.

${ }^{79}$ Barnard, Kingdom of Ireland, 82; Magennis, "Coal, Corn and Canals," 86.

${ }^{80}$ S. R. Epstein, Freedom and Growth: The Rise of States and Markets in Europe, 1300-1750 (London, 2000), 6. Also J. P. Greene, Negotiated Authorities: Essays in Colonial Political and Constitutional History (Charlottesville, VA, 1994), 11, 23.

${ }^{81}$ Michael Hechter, Internal Colonialism: The Celtic Fringe in British National Development, 15361966 (London, 1975). 
orated after 1688, marking an important step in the evolution of Britain and Ireland from a "multiple kingdom" to a "composite state" of unequal parts. ${ }^{82}$

It was also the case that domestically the state in Britain was more multilayered and multistranded than is usually appreciated, such that to focus only upon fiscalmilitary or mercantilist considerations is to miss too much. Moreover, neither the authority of the British fiscal-military state nor the pursuit or experience of legislation was felt consistently across Britain (or indeed the four nations). The application of general legislation was often patchy in national terms, but this article has also stressed the need to consider all types of legislation-that parliament influenced the economy through both broad and specific measures. The latter were very numerous, collectively influencing economic activity profoundly and extensively. But there were very clear differences in the scope and subject matter of the legislation of the three parliaments; specific interests sought legislation at all three, but this was much more marked in the case of the English at Westminster. Crucially, Scotland, which had generated so much legislation before 1707, developed in the eighteenth century without resorting to Westminster for legislation on a significant scale. Moreover, if the explanation for its economic success is put down to incorporation within England's empire with union, then such an argument plainly cannot be made in the Irish case after 1800. Before then, the Dublin parliament was available to economic interests through the eighteenth century, especially from 1782, and invested significant amounts of public funds in schemes for economic improvement, yet even then Ireland's economy did not develop along British lines. ${ }^{83}$

The Welsh case has pointed to the need to take into account differences in the demand for legislation from propertied interests, demand that reflected the perceived potential of the underlying economy. From this perspective the state can reasonably be designated as "reactive." In turn, the power of political institutions should not be exaggerated relative to fundamentals such as the geographical distribution of vital raw materials. But that does not mean that Westminster was a neutral or passive institution that can be lightly discounted. Not only did it legislate extensively relating to economic matters, but such legislation might be consequent upon significantly changing notions of property rights and market fundamentals, as the cases of the Corn Laws, enclosure, and slavery attest.

A further crucial point suggested by this article is that the Westminster parliament was not straightforwardly the sovereign power at the center of a single, unitary jurisdiction. In practice it also sat amid other forms of authority, often quite strong ones. The Scottish case is especially important here. Its propertied interests sought relatively little legislation at Westminster. An important part of the explanation appears to be due to the strength of other institutions closer to home, especially the Convention of the Royal Burghs and the Court of Session. As yet very little is known about the work undertaken in them, either in the round or in relation

${ }^{82}$ J. H. Elliott, "A Europe of Composite Monarchies," Past and Present, no. 137 (November 1992): 48-71; H. G. Koenigsberger, "Composite States, Representative Institutions and the American Revolution," Historical Research 62, no. 148 (June 1989): 135-53; David Hayton, "Constitutional Experiments and Political Expediency, 1689-1725," in Ellis and Barber, Conquest and Union, 276-305.

${ }^{83}$ Interesting points are made in S. J. Connolly, R. A. Houston, and R. J. Morris, "Identity, Conflict and Economic Change: Themes and Issues," in Conflict, Identity and Economic Development: Ireland and Scotland, 1600-1939, ed. S. J. Connolly, R. A. Houston, and R. J. Morris (Preston, 1995), 1-13. 
to economic activity, but it does seem reasonable to conclude that the strength of Scotland's civic institutions was indeed such that in this period "Scottish sovereignty became modern and dynamic, but it was not associated with a parliament." ${ }^{84}$ Even in the case of England and Wales it is worth remembering that many disputes over property might be resolved either by act of parliament or by a chancery decree and that the latter were numerous both before and after $1688 .^{85}$ And if parliament made laws, judges applied them, often with considerable discretion, perhaps especially in Scotland. ${ }^{86}$ The proliferation of statutes in this period only increased the opportunity for judicial discretion.

Such complexities play, of course, upon broader visions of the trajectories of British history. Britain has been an inherently multinational state since at least 1603 but not a unitary, federal, or confederal one. If it might be called a "union state," the nature of the union has gone through more substantial twists and turns than is often acknowledged. ${ }^{87}$ The Glorious and the industrial revolutions were part of that, while the links (and, in places, the absence of links) from the former to the latter bring out some of the meaning of the twists and turns. This can suggest a very different view than both the old and the new Whig interpretation, of fluctuation as well as achievement; of divergence as well as of convergence; and, in particular, of uncertainty and ambiguity in connections between the individual, the nation, and the state. Mischievously, it might be recalled that, in fact, the Whig interpretation always existed alongside that of "perfidious Albion," of a country inclined to kill its kings, abandon its allies, bully its neighbors, and posture hypocritically. ${ }^{88}$

This is not, however, to deny the distinctive nature of Britain's history between the late seventeenth and late eighteenth centuries. The consequences of the Glorious Revolution and the growth of Britain's economy in the eighteenth century were unusual. ${ }^{89}$ But a distinctive history is not necessarily an exemplary one. Indeed, as O'Brien and Bates have argued, on a priori grounds it seems reasonable to argue that Britain's economic precocity made it ill suited to provide a guide

\footnotetext{
${ }^{84}$ Alexander Murdoch, "Scottish Sovereignty in the Eighteenth Century," in The Challenge of Westminster: Sovereignty, Devolution and Independence, ed. H. T. Dickinson and M. Lynch (East Lothian, $2000), 49$.

${ }^{85}$ Henry Horwitz and Patrick Polden, "Continuity or Change in the Court of Chancery in the Seventeenth and Eighteenth Centuries?" Journal of British Studies 35, no. 1 (January 1996): 24-57.

${ }^{86}$ Connolly, Houston, and Morris, "Identity, Conflict and Economic Change," 2.

${ }^{87}$ McLean and McMillan, State of the Union, 6.

${ }^{88}$ H. D. Schmidt, "The Idea and Slogan of 'Perfidious Albion," Journal of the History of Ideas 14, no. 4 (October 1953): 604-16; David A. Bell, The Cult of the Nation in France: Inventing Nationalism, 1680-1800 (Cambridge, MA, 2001), chap. 3; Frances Acomb, Anglophobia in France, 1763-1789: An Essay in the History of Constitutionalism and Nationalism (Durham, NC, 1950); Norman Hampson, The Perfidy of Albion: French Perceptions of England during the French Revolution (Houndmills, 1998); Bernard Crick, "The English and the British," in National Identities: The Constitution of the United Kingdom, ed. B. Crick (Oxford, 1991), 96.

${ }^{89}$ I go some of the way with Steve Pincus, 1688: The First Modern Revolution (New Haven, CT, 2009), but I put much greater weight on the collective importance of specific legislation and the multinational aspects of political action than he does.
} 
for later industrial revolutions. ${ }^{90}$ This article has provided considerable evidence in support of such a revision, for the British state was multinational and multilayered in ways impossible to mimic. Not the least of its achievements was to provide various ways in which political and legal power might be used to pursue economic opportunities. If not all of those variations arose because of three or four nations' considerations, it is nonetheless clear that a single nation-state perspective is only a part of the story; better, indeed, to recognize the plurality of Britain's political economies.

${ }^{90}$ O'Brien, "The Britishness of the First Industrial Revolution," 50-51; Robert H. Bates, "Lessons from History, or the Perfidy of English Exceptionalism and the Historical Significance of France," World Politics 15, no. 4 (July 1988): 499-516. Some suggestive points are also made by Jeff Horn, The Path Not Taken: French Industrialization in the Age of Revolution, 1750-1830 (Cambridge, MA, 2006), chap. 1 . 